\title{
TESTE DE INTEGRIDADE NO SETOR PRIVADO: ESTADO DA ARTE
}

\author{
INTEGRITY TEST IN THE PRIVATE SECTOR: STATE OF ART
}

\section{TEST DE INTEGRIDAD EN EL SECTOR PRIVADO: ESTADO DEL ARTE}

\author{
JULIO CESAR DE AGUIAR \\ https://orcid.org/0000-0002-8252-2894 / http://lattes.cnpq.br/7152243130773982 / juliocesar.deaguiar@gmail.com \\ Universidade Católica de Brasília. \\ Brasília, DF, Brasil.
}

FLÁVIO PEREIRA DA COSTA MATIAS
https://orcid.org/0000-0002-1645-8193 / http://lattes.cnpq.br/8787354437610775 / flaviopcmatias@gmail.com Universidade Católica de Brasília. Brasília, DF, Brasil.

\section{RESUMO}

Este artigo visa discutir como o teste de integridade é utilizado no setor privado no Brasil e a respectiva compatibilidade com a legislação brasileira. Primeiramente, o artigo busca examinar a aplicação do compliance no direito comparado e no brasileiro, especificamente sob o Foreign Corrupt Practices Act (EUA), o Bribery Act 2010 (UK) e a Lei 12.846/2013. O estudo também analisa o teste de integridade, suas origens e modalidades. Após, o artigo discute a aplicação do teste de integridade no setor privado e o estado da arte do uso do teste de integridade como uma ferramenta de compliance no direito comparado e na legislação brasileira, para concluir que a aplicação de testes de integridade no setor privado tem respaldo na lei para fazer parte de programas de conformidade, tanto no Brasil como no exterior. O método utilizado para o artigo foi a pesquisa bibliográfica, de natureza exploratória, utilizando a legislação brasileira, a legislação do Reino Unido e a legislação estadunidense como referências de análise.

Palavras-chave: Conformidade; Direito comparado; Teste de Integridade; Setor privado.

\begin{abstract}
This paper aims to discuss how integrity testing is utilized in the private sector in Brazil and its compatibility with Brazilian Law. At first, the paper seeks to examine the enforcement of compliance in comparative and Brazilian law, specifically under the Foreign Corrupt Practices Act (USA), The Bribery Act 2010 (UK), and the Brazilian Law $12.846 / 2013$. The study also analyzes the integrity test, its origin and its types. Then the article discusses the application of the integrity test in the private sector and the state of art of the use of integrity tests as a compliance tool in comparative and Brazilian law, to conclude that the integrity tests in private sector have support in law to be part of the compliance programs, inside and outside Brazil. The methodology of this paper is the bibliographical research, of exploratory nature, taking the Brazilian law, the UK law, and the American law as references of analysis.
\end{abstract}

Keywords: Compliance; Comparative law; Integrity test; Private sector.

\section{RESUMEN}

Este artículo pretende discutir cómo se utilizan los tests de la integridad en el sector privado en Brasil y su compatibilidad con la legislación brasileña. Primero, el artículo trata de examinar la aplicación del cumplimiento en la ley comparativa y brasileña, específicamente bajo el Foreign Corrupt Practices Act (EE. UU.), el Bribery Act 2010 (UK) y la Ley 12.846/2013. El estudio también analiza el test de la integridad, sus orígenes y modalidades. En el siguiente, el artículo analiza la aplicación de los tests de la integridad en el sector privado y el estado del arte del uso de los tests de la integridad como una herramienta de cumplimiento en el derecho comparado y la ley brasileña, para concluir que la aplicación de los tests de la integridad en el sector privado tiene bases en la legislación para formar parte de programas de cumplimiento tanto en Brasil como en el exterior. El método utilizado para el artículo fue la investigación bibliográfica exploratoria, utilizando la legislación brasileña, la legislación del Reino Unido y la legislación estadounidense como referencias para el análisis.

Palabras clave: Conformidad; Derecho comparado; Test de Integridad; Sector privado. 


\section{SUMÁRIO}

INTRODUÇÃO; 1 COMPLIANCE E NORMAS ANTICORRUPÇÃO; 1.10 Foreign Corrupt Practices Act (FCPA); 1.20 United Kingdom Bribery Act 2010 (UKBA); 1.3 A Lei Anticorrupção Empresarial brasileira; 20 TESTE DE INTEGRIDADE; 2.1 As 10 Medidas Contra a Corrupção e o teste de integridade no setor público; 2.20 teste de integridade no setor privado; 3 OS PROGRAMAS DE COMPLIANCE E 0 TESTE DE INTEGRIDADE; 3.10 teste de integridade e o FCPA; 3.20 teste de integridade e o UKBA; 3.3 $O$ teste de integridade e a norma ABNT NBR ISO 37001; 3.40 teste de integridade, a Lei 12.846/2013 e o Decreto 8.420/2015; CONCLUSÃO; REFERÊNCIAS.

\section{INTRODUÇÃO}

Em $1^{\circ}$ dezembro de 2016, o grupo Odebrecht divulgou na imprensa um release intitulado “Desculpe, a Odebrecht errou”, no qual reconheceu ter participado de "práticas impróprias em sua atividade empresarial”, violando os próprios princípios e agredindo valores consagrados de honestidade e ética.

Àquela época, já haviam transcorrido mais de dois anos e meio do início da Operação Lava Jato, investigação articulada pelo Ministério Público Federal, Polícia Federal, Receita Federal do Brasil, dentre outros, e o ex-presidente do grupo Odebrecht, Marcelo Bahia Odebrecht, estava preso há cerca de um ano e meio.

No comunicado, além admitir o envolvimento em práticas espúrias, o grupo Odebrecht registrou um "Compromisso com o Futuro" com dez itens a serem por ele rigorosamente observados, dos quais convém destacar o item 7 (Garantir na Odebrecht, e em toda a cadeia de valor dos Negócios, a prática do Sistema de Conformidade, sempre atualizado com as melhores referências) e o 9 (Incorporar nos Programas de Ação dos Integrantes avaliação de desempenho no cumprimento do Sistema de Conformidade).

O compromisso do grupo Odebrecht é representativo de uma nova era no trato da corrupção praticada por agentes privados. A Odebrecht, que por ocasião da prisão de seus executivos e diretores, divulgou comunicado na imprensa declarando possuir Código de Conduta e Sistema de Conformidade ${ }^{1}$, sentiu as consequências pecuniárias de não aplicar suas normas de compliance, ao celebrar acordo de leniência, e a necessidade de adotar e principalmente de executar efetivamente programas de integridade. Segundo estimativa da Engineering News

1 ODEBRECTH. Comunicado Odebrecht - Operación Lava Jato. 22 jun. 2015. Disponível em: https://www.odebrecht.com/es/comunicacion/releases/comunicado-odebrecht-operacion-lava-jato. Acesso em: 10 mai. 2018. 
Record, a empresa passou da posição de $6^{a}$ maior construtora do mundo, em 2016, para a $29^{a}$ colocação em $2017^{2}$, após eclodirem os escândalos de corrupção envolvendo empresas do grupo não apenas no Brasil, mas também em outros países da América Latina.

A história recente do grupo Odebrecht faz parte de um processo mais amplo de exigência global de novos standards de integridade e conformidade para o setor privado. A corrupção não é mais vista como um problema unicamente do serviço público. 0 pagamento de propina é um ato bilateral: tanto a esfera pública como a privada estão envolvidas no ato de corrupção ${ }^{3}$.

E os danos causados pelo pagamento disseminado de suborno na relação público-privado vão muito além da violação à ética de agentes públicos, passando pelo desequilíbrio no mercado e na concorrência, pelo capitalismo de compadrio, pela ineficiência das atividades estatais, pela quebra de confiança nas instituições e pelo enfraquecimento da democracia e do caráter cívico da população. Por essas razões, organismos multilaterais e Estados vêm se voltando para o enfrentamento da corrupção, tanto repressiva como preventivamente, por meio de tratados e legislações nacionais.

É nesse contexto que surgem os programas de integridade e de conformidade, tradução para a palavra inglesa compliance. 0 objetivo geral deste estudo é investigar o tratamento dado no Brasil e no direito comparado ao compliance e especificamente a uma de suas ferramentas, o teste de integridade.

O problema que se discute neste artigo diz respeito à compatibilidade entre a aplicação no setor privado do teste de integridade e o ordenamento jurídico pátrio. Para enfrentá-lo, na primeira seção iniciar-se-á por uma abordagem sobre os programas de compliance e a respectiva previsão legal e regulamentação nos Estados Unidos da América, no Reino Unido e no Brasil.

Na segunda seção, abordar-se-á o teste de integridade e como se deu a sua aparição no cenário nacional, no bojo da campanha 10 Medidas Contra a Corrupção. Explicar-se-ão as diferenças entre o teste de integridade de agentes públicos e o teste de integridade no setor privado.

$\mathrm{Na}$ terceira seção, será feita uma breve digressão sobre a legislação anticorrupção dos Estados Unidos e do Reino Unido e as relações respectivas com o teste de integridade no setor privado. Igualmente, far-se-á uma incursão na norma antissuborno ISO 37001, já reconhecida

2 ENGINEERING NEWS-RECORD (ENR). ENR's 2017 Top 250 International Contractors 1-100. Ago. 2017. Disponível em: https://www.enr.com/toplists/2017-Top-250-International-Contractors-1. Acesso: 20 mai. 2018.

${ }^{3}$ MUNGIU-PIPPIDI, Alina. The quest for good governance: how societies develop control of corruption. London: Cambridge University Press, 2015. p. 12. 
nacionalmente pela Associação Brasileira de Normas Técnicas, e sua correlação com o teste de integridade em corporações. Ao final, analisar-se-á a legislação anticorrupção no Brasil e o tratamento jurídico que pode ser conferido à utilização de testes de integridade no setor privado.

A hipótese que se constrói é a de que ao teste de integridade no setor privado nacional não se prestam as críticas feitas ao teste de integridade de agentes públicos, de maneira que a sua assimilação pelos programas de compliance das corporações encontra respaldo na Lei 12.846, de 2013, e no Decreto 8.420, de 2015.

Para tanto, o método utilizado foi a pesquisa bibliográfica, de natureza exploratória, utilizando a legislação brasileira, a legislação do Reino Unido e a legislação estadunidense como referências de análise, à míngua de produções acadêmicas sobre o tema deste trabalho, pois durante a investigação constatou-se a escassez bibliográfica sobre o tema no panorama nacional, inexistindo artigo ou outro texto científico abordando a juridicidade do teste de integridade no setor privado no âmbito dos programas de compliance.

\section{COMPLIANCE E NORMAS ANTICORRUPÇÃO}

A palavra compliance é oriunda do verbo inglês to comply, que significa sujeitar-se a, estar de acordo, corresponder, cumprir, satisfazer ou realizar ${ }^{4}$, e pode ser traduzida sem prejuízo no significado por conformidade ${ }^{5}$.

É possível definir o compliance como o dever de cumprir, de estar em conformidade e fazer cumprir leis, diretrizes e regulamentos internos, procedimentos e práticas recomendáveis ou obrigatórias pela legislação vigente ${ }^{6}$. Naturalmente, os níveis aceitáveis de compliance modificam-se ao longo do tempo e diferem dependendo do contexto ${ }^{7}$.

\footnotetext{
${ }^{4}$ UBALDO, Flávia Safadi. Lei Anticorrupção: a importância do programa de compliance no cenário atual. In: O compliance como instrumento de prevenção e combate à corrupção. PORTO, Vinicius; MARQUES, Jader (org). Porto Alegre: Livraria do Advogado, 2017. p. 121

${ }^{5}$ FONSECA, João Bosco Leopoldino da. Conformidade Legal. In: Compliance e integridade: aspectos teóricos e práticos. OLIVEIRA, Luiz Gustavo Miranda de (org.). Belo Horizonte: D'Plácido, 2017. p. 94.

${ }^{6}$ ADACHI, Pedro Podboi. Governança, risco e compliance nas empresas familiares. In: Tendências em governança corporativa e compliance. SAAD-DINIZ, Eduardo; ADACHI, Pedro Podboi; DOMINGUES, Juliana Oliveira (org). São Paulo: LiberArs, 2016. p. 69.

7 VERSLUIS, Esther. Compliance Problems in the EU. What potential role for agencies in securing compliance? Paper prepared for the 3rd ECPR General Conference, Budapest, 8-10 September 2005 Panel 3.3: 'Theorizing Regulatory Enforcement and Compliance', p. 5. Disponível em: http://regulation.upf.edu/ecpr-05-papers/eversluis.pdf. Acesso em: 5 mai. 2018.
} 
Em termos práticos, o compliance trata-se de um programa a ser desenvolvido por uma equipe específica e treinada dentro das organizações para os fins de controle da conformidade da empresa com os regulamentos e leis ${ }^{8}$. 0 programa de compliance adotado por uma empresa visa estabelecer mecanismos e procedimentos que tornem o cumprimento da legislação parte da cultura corporativa, minimizando as possibilidades de que ilícitos ocorram e criando ferramentas para que a empresa identifique rapidamente e lide de modo adequado com a ocorrência de práticas indesejadas. A função do compliance é, assim, prevenir, monitorar e assegurar que todos os envolvidos com uma empresa estejam de acordo com as práticas de condutas dela?

A busca por um mercado ético e saudável, no qual os agentes competem em pé de igualdade e se atinge maior eficiência, certamente contribuiu para a gradativa redução da tolerância com a corrupção - aqui aludida em sentido amplo - tanto interna como externamente e, por tabela, para a disseminação de programas de compliance.

Em São Paulo, convém registrar a iniciativa da Bovespa (ora denominada B3) ao lançar em 2000 uma classificação para dimensionar aos investidores o nível de adesão das empresas de capital aberto à Governança Corporativa, do qual o Novo Mercado corresponde ao maior nível de adesão às regras de Governança ${ }^{10}$. 0 art. 24 do Regulamento do Novo Mercado dispõe que "a companhia deve implantar funções de compliance, controles internos e riscos corporativos, sendo vedada a acumulação com atividades operacionais"11.

No entanto, é inegável que num primeiro momento a aplicação rigorosa de novas legislações ao redor do mundo foi a força motriz da superação da complacência com que se encarava a corrupção ${ }^{12}$.

Uma breve explanação sobre as principais legislações anticorrupção no mundo é oportuna para posteriormente se voltar os olhos ao lugar do compliance no Brasil e, especificamente, sobre as possibilidades do teste de integridade no setor privado.

\footnotetext{
8 LIMA, Carlos Fernando dos Santos; MARTINEZ, André Almeida Rodrigues. Compliance Bancário: Um Manual Descomplicado. São Paulo: Quartier Latin, 2018. p. 47

9 UBALDO, Flávia Safadi. Lei Anticorrupção: a importância do programa de compliance no cenário atual. In: O compliance como instrumento de prevenção e combate à corrupção. PORTO, Vinicius; MARQUES, Jader (org). Porto Alegre: Livraria do Advogado, 2017. p. 121.

${ }_{10}$ LIMA, Carlos Fernando dos Santos; MARTINEZ, André Almeida Rodrigues. Compliance Bancário: Um Manual Descomplicado. São Paulo: Quartier Latin, 2018. p. 37.

11 B3. Regulamento do Novo Mercado. Disponível em: http: / / www.bmfbovespa.com.br/lumis/portal/file/fileDownload.jsp?>fileld=8AA8D0976069F0D701606FEE C81D2597. Acesso em: 5 mai. 2018. p. 17.

12 MAEDA, Bruno Carneiro. Programas de Compliance Anticorrupção: importância e elementos essenciais. In: Temas de Anticorrupção e Compliance. DEL DEBBIO, Alessandra; MAEDA, Bruno Carneiro; AYRES, Carlos Henrique da Silva (org.). Rio de Janeiro: Elsevier, 2013. p. 168.
} 


\subsection{O Foreign Corrupt Practices Act (FCPA)}

A disseminação e aceitação dos programas de compliance anticorrupção possui profunda influência da legislação norte-americana, sobretudo a partir do final dos anos 70 do século passado. Após a eclosão do escândalo Watergate, o Congresso dos Estados Unidos editou, em 1977, o Foreign Corrupt Practices Act (FCPA) ${ }^{13}$, considerado pela literatura como o primeiro passo importante no enfrentamento da corrupção comercial transnacional ${ }^{14}$.

O FCPA alcançou vasta aplicação em face de empresas norte-americanas e estrangeiras devido a sua jurisdição ser bastante alargada, atingindo, exemplificativamente, uma pessoa jurídica estabelecida sob as leis estadunidenses ou que tenha nos Estados Unidos sua principal sede de negócios. Da mesma forma, quaisquer problemas envolvendo o comércio exterior estadunidense atrai a jurisdição dos Estados Unidos ${ }^{15}$.

O surgimento do FCPA no ano de 1977 antecedeu a abertura de mercado que marcou os governos norte-americano e britânico na década de 80 (governos Reagan e Thatcher, respectivamente). Essa é a razão apontada pela literatura para o texto legal não fazer nenhuma referência às exigências de compliance, ou aos efeitos que a adoção de tais práticas pelas empresas poderia causar na responsabilização por atos de corrupção ${ }^{16}$.

A ausência de previsão legal no FCPA de normas de compliance, entretanto, não significa que a exigência de conformidade inexista nos Estados Unidos.

O sistema processual norte-americano é nitidamente acusatório e tem como característica marcante a discricionariedade, segundo a qual o órgão responsável pela acusação deve sempre fazer uma análise de custo-benefício para decidir se deve ou não ajuizar uma acusação criminal em um dado caso concreto ${ }^{17}$. Assim é que o United States Department of

13 THE UNITED STATES DEPARTMENT OF JUSTICE. Foreign Corrupt Practices Act of 1977. Disponível em: https://www.justice.gov/criminal/fraud/fcpa/docs/fcpa-english.pdf. Acesso em: 12 mar. 2018.

14 VERÍSSIMO, Carla. Compliance: incentivo de adoção de medidas anticorrupção. São Paulo: Saraiva, 2017. p. 150.

15 ZAGARIS, Bruce. Transnational corruption in Brazil: the relevance of the U.S. experience with the Foreign Corrupt Practices Act. In: Temas de Anticorrupção e Compliance. DEL DEBBIO, Alessandra; MAEDA, Bruno Carneiro; AYRES, Carlos Henrique da Silva (org.). Rio de Janeiro: Elsevier, 2013. p. 59.

${ }^{16}$ CARVALHO, Paulo Roberto Galvão de. Legislação anticorrupção no mundo: análise comparativa entre a Lei Anticorrupção brasileira, o Foreign Corrupt Practices Act norte-americano e o Bribery Act do Reino Unido. In: Lei Anticorrupção. QUEIROZ, Ronaldo Pinheiro de; SOUZA, Jorge Munhós (org.). Salvador: Juspodivm, 2015. p. 52

${ }_{17}$ CARVALHO, Paulo Roberto Galvão de. Legislação anticorrupção no mundo: análise comparativa entre a Lei Anticorrupção brasileira, o Foreign Corrupt Practices Act norte-americano e o Bribery Act do Reino 
Justice, por meio do U.S. Attorney's Manual ${ }^{18}$, estabelece que os promotores, ao decidir sobre o ato de ajuizar uma ação penal, devem avaliar a existência de programas de compliance não apenas no papel, mas na implementação, revisão e aplicação efetiva.

A previsão para que os promotores levem em consideração a existência e efetiva implementação de programas de compliance ao decidir sobre o ajuizamento de ações penais somente foi inserida numa versão revisada e publicada em 2006 do U.S. Attorney's Manual e foi fundamental para incentivar de modo substancial a adoção de posturas proativas na implementação de programas de compliance ${ }^{19}$.

Ainda nos Estados Unidos, o documento intitulado U.S. Sentencing Guidelines, que fornece diretrizes à aplicação de sanções às autoridades norte-americanas, fixa os montantes de redução da pena de acordo com a existência de programas de compliance efetivos ${ }^{20}$.

Tudo isso demonstra a relevância que um programa de compliance bem implementado possui na aplicação da legislação anticorrupção norte-americana.

\subsection{United Kingdom Bribery Act 2010 (UKBA)}

Em 2010, o Reino Unido promulgou uma nova lei anticorrupção, conhecida como Bribery Act e referida na literatura como United Kingdom Bribery Act (UKBA) ${ }^{21}$.

O Bribery Act criou quatro condutas: duas relacionadas a oferecer e receber suborno; uma terceira sobre subornar um funcionário público estrangeiro; e uma quarta, relativa à falha de empresas em prevenir a prática de corrupção. A norma anticorrupção do Reino Unido, o

Unido. In: Lei Anticorrupção. QUEIROZ, Ronaldo Pinheiro de; SOUZA, Jorge Munhós (org.). Salvador: Juspodivm, 2015. p. 52

18 OFFICE OF THE UNITED STATES ATTORNEYS. United States Attorney's Manual - USAM. Disponível em: https://www.justice.gov/usam/usam-9-28000-principles-federal-prosecution-business-organizations\#9-

28.800. Acesso em: 3 mai. 2018.

${ }^{19}$ MAEDA, Bruno Carneiro. Programas de Compliance Anticorrupção: importância e elementos essenciais. In: Temas de Anticorrupção e Compliance. DEL DEBBIO, Alessandra; MAEDA, Bruno Carneiro; AYRES, Carlos Henrique da Silva (org.). Rio de Janeiro: Elsevier, 2013. p. 172.

${ }^{20}$ MAEDA, Bruno Carneiro. Programas de Compliance Anticorrupção: importância e elementos essenciais. In: Temas de Anticorrupção e Compliance. DEL DEBBIO, Alessandra; MAEDA, Bruno Carneiro; AYRES, Carlos Henrique da Silva (org.). Rio de Janeiro: Elsevier, 2013. p. 173.

21 THE NATIONAL ARCHIVES. United Kingdom Bribery Act 2010. Disponível em: https://www.legislation.gov.uk/ukpga/2010/23/contents. Acesso em: 12 mar. 2018. 
UKBA, foi além do FCPA norte-americano, na medida em que regulou tanto a corrupção pública como a privada ${ }^{22}$.

Um dos maiores destaques da legislação britânica é a importância conferida aos programas de compliance. Ao erigir à categoria de ilícito penal autônomo a simples conduta de falhar na prevenção da corrupção, o UKBA transfere ao particular todo o ônus de prevenir a prática de atos de corrupção em qualquer elo da cadeia de negócios da empresa, tornando-o responsável por desenhar, implementar, aplicar e avaliar sua própria regulamentação ${ }^{23}$.

Da mesma forma, ao criminalizar a falha em prevenir a corrupção, o Bribery Act confere um estímulo à adoção de programas de compliance bem mais impactante do que o existente no FCPA, em que o compliance efetivo é basicamente avaliado no momento de se oferecer ou não uma ação criminal, bem como ao se fixar a sanção adequada.

Entretanto, a norma anticorrupção do Reino Unido, assumindo a impossibilidade fática de se evitar completamente a prática do suborno, reputa uma defesa eficaz para a empresa a existência e aplicação de procedimentos adequados de compliance (UKBA, Section 7, (2)).

Fica evidente, com mais vigor do que no FCPA, a imposição da legislação anticorrupção britânica para que as empresas adotem programas de compliance efetivos com o intuito de obstar a prática de atos de corrupção e, inclusive, evitar a responsabilização pelo crime autônomo de falhar ao prevenir a corrupção.

\subsection{A Lei Anticorrupção Empresarial brasileira}

A Lei 12.846 , de $1^{\circ}$ de agosto de 2013, conhecida como Lei Anticorrupção Empresarial $(\mathrm{LAE})^{24}$, constitui um marco na legislação nacional ao prever a responsabilização cível objetiva e administrativa de pessoas jurídicas pela prática de atos de corrupção.

22 NASCIMENTO, José Carlos Martins do. Compliance e legislação internacional. In: Compliance e integridade: aspectos teóricos e práticos. OLIVEIRA, Luiz Gustavo Miranda de (org.). Belo Horizonte: D'Plácido, 2017. p. 252.

${ }^{23}$ CARVALHO, Paulo Roberto Galvão de. Legislação anticorrupção no mundo: análise comparativa entre a Lei Anticorrupção brasileira, o Foreign Corrupt Practices Act norte-americano e o Bribery Act do Reino Unido. In: Lei Anticorrupção. QUEIROZ, Ronaldo Pinheiro de; SOUZA, Jorge Munhós (org.). Salvador: Juspodivm, 2015. p. 53.

${ }^{24}$ BRASIL. Lei $n^{\circ} 12.846$, de $1^{\circ}$ de agosto de 2013 . Dispõe sobre a responsabilização administrativa e civil de pessoas jurídicas pela prática de atos contra a administração pública, nacional ou estrangeira, e dá outras providências. In: Diário Oficial da República Federativa do Brasil, Brasília, DF, 2 ago. 2013. Disponível em: http://www.planalto.gov.br/ccivil_03/_ato2011-2014/2013/lei/l12846.htm. Acesso em: 10 mar. 2018. 
Editada para "suprir uma lacuna no sistema jurídico pátrio no que tange à responsabilização de pessoas jurídicas por atos lesivos à Administração Pública nacional e estrangeira", conforme versa sua exposição de motivos $^{25}$, a Lei 12.846/2013 tem origem nos diversos tratados e convenções internacionais anticorrupção aos quais o Brasil aderiu, como a Convenção sobre o Combate da Corrupção de Funcionários Públicos Estrangeiros em Transações Comerciais Internacionais, da Organização para a Cooperação e Desenvolvimento Econômico, concluída em Paris, em 17 de dezembro de 1997 e internalizada ao ordenamento jurídico nacional por meio do Decreto 3.678/2000; a Convenção Interamericana contra a Corrupção, adotada no âmbito da Organização dos Estados Americanos em Caracas, em 29 de março de 1996, e internalizada por meio do Decreto 4.410/2002; e a Convenção das Nações Unidas contra a Corrupção, conhecida como Convenção de Mérida, adotada pela Assembleia-Geral das Nações Unidas em 31 de outubro de 2003 e internalizada pelo Decreto 5.687/2006.

Embora a literatura aponte que a Lei Anticorrupção Empresarial pretende responsabilizar pessoas jurídicas pela prática de crimes de corrupção previstos nas convenções internacionais citadas no parágrafo antecedente ${ }^{26}$, o legislador deliberadamente rejeitou a ideia de responsabilização criminal sob o pretexto de que "o Direito Penal não oferece mecanismos efetivos ou céleres para punir sociedades empresárias", ao passo que "o processo administrativo [...] tem-se revelado mais célere e efetivo na repressão de desvios em contratos administrativos e procedimentos licitatórios, demonstrando melhor capacidade de proporcionar respostas rápidas à sociedade" 27 .

A Lei 12.846/2013 não impõe a adoção de ferramentas de compliance a pessoas jurídicas empresariais. Inexiste na LAE punição, seja administrativa, civil ou criminal, para a empresa que deixar de implementar um programa de integridade e medidas de conformidade.

$\mathrm{Na}$ verdade, consoante anota Veríssimo ${ }^{28}$, a lei conferiu aos programas e mecanismos de compliance unicamente o efeito de influir no cálculo da multa administrativa, ao discorrer, no art. $7^{\circ}$, que "serão levados em consideração na aplicação das sanções" administrativas, dentre

\footnotetext{
25 SUBCHEFIA DE ASSUNTOS PARLAMENTARES. EMI Nº 000112009 - CGU/MJ/AGU. Brasília, 23 out. 2009. Disponível em: http://www.planalto.gov.br/ccivil_03/projetos/EXPMOTIV/EMI/2010/11\%20\%20CGU\%20MJ\%20AGU.htm. Acesso em: 8 abr. 2018.

26 VERÍSSIMO, Carla. Compliance: incentivo de adoção de medidas anticorrupção. São Paulo: Saraiva, 2017. p. 178.

27 SUBCHEFIA DE ASSUNTOS PARLAMENTARES. EMI No 000112009 - CGU/MJ/AGU. Brasília, 23 out. 2009. Disponível em: http://www.planalto.gov.br/ccivil_03/projetos/EXPMOTIV/EMI/2010/11\%20\%20CGU\%20MJ\%20AGU.htm. Acesso em: 8 abr. 2018.

${ }^{28}$ VERÍSSIMO, Carla. Compliance: incentivo de adoção de medidas anticorrupção. São Paulo: Saraiva, 2017. p. 243.
} 
outros aspectos, "a existência de mecanismos e procedimentos internos de integridade, auditoria e incentivo à denúncia de irregularidades e a aplicação efetiva de códigos de ética e de conduta no âmbito da pessoa jurídica" (VIII).

A tibieza do incentivo legal à adoção de programas de compliance, tão somente um fator dentre vários outros para redução exclusivamente de sanção administrativa, foi percebida por equipe de avaliadores da Organização para Cooperação e Desenvolvimento Econômico OCDE, que, ao visitar o Brasil em 2014 para avaliar o cumprimento da Convenção sobre o Combate da Corrupção de Funcionários Públicos Estrangeiros em Transações Comerciais Internacionais e elaborar o relatório da Fase 3 de seu cumprimento, consignou a preocupação com essa limitação, afirmando que ela atenuaria o impacto do incentivo para adoção dos programas de compliance pelas pessoas jurídicas ${ }^{29}$.

Por esse motivo, Veríssimo ${ }^{30}$ defende que "o efeito mitigador dos programas e mecanismos de compliance sob a Lei n. 12.846/2013 não configura um incentivo adequado para que as empresas desenvolvam tais programas", de maneira que mais valeria que o compliance pudesse ao menos ser considerado também na aplicação das sanções cíveis, no âmbito do processo judicial ${ }^{31}$.

Apesar de a Lei Anticorrupção Empresarial não obrigar as empresas à implantação de mecanismos e programas de compliance, o mercado está cada vez mais exigente, como se exemplificou ao tratar brevemente do surgimento do Novo Mercado no âmbito da B3, e globalizado, de modo que companhias brasileiras que atuam internacionalmente podem vir a se sujeitar ao FPCA e UKBA, para os quais o compliance detém outro patamar de importância em relação à ordem jurídica brasileira.

Ademais, ao prevenir a ocorrência de violações legais, o programa de compliance também auxilia na manutenção de uma boa reputação pela sociedade empresária e evita, com isso, a ocorrência de danos relacionados à sua perda ${ }^{32}$.

Dessa forma, é razoável considerar que, mesmo no Brasil, o compliance tende a se inserir cada vez mais no dia a dia das empresas e que mais cedo ou mais tarde a inexistência de

29 ORGANIZAÇÃO PARA COOPERAÇÃO E DESENVOLVIMENTO ECONÔMICO - OCDE. Phase 3 report on implementing the OECD Anti-Bribery Convention in Brazil Outubro de 2014. p. 28. Disponível em: www.oecd.org/daf/anti-bribery/Brazil-Phase-3-Report-EN.pdf. Acesso em: 15 abr. 2018.

30 VERÍSSIMO, Carla. Compliance: incentivo de adoção de medidas anticorrupção. São Paulo: Saraiva, 2017. p. 265.

31 VERISSIMO, Carla. Compliance: incentivo de adoção de medidas anticorrupção. São Paulo: Saraiva, 2017. p. 266-267.

32 CASTRO, Marina Grimaldi. O programa de compliance corporativo. In: Compliance no ordenamento jurídico brasileiro. DUTRA, Lincoln Zub (org.). Curitiba: Juruá, 2018. p. 164. 
programas de conformidade efetivos e adequados ao porte das companhias será uma exceção que deixará as empresas omissas em franca desvantagem competitiva e menos atrativas aos investidores.

Feitas essas considerações sobre o compliance, passa-se a analisar o teste de integridade e a examinar se e como ele pode integrar os programas de conformidade.

\section{O TESTE DE INTEGRIDADE}

No presente estudo, pretende-se abordar as possibilidades do teste de integridade no setor privado.

Antes, entretanto, é indispensável discorrer fugazmente sobre o teste de integridade no setor público - onde possui outra formatação -, tendo em vista que ele ganhou destaque justamente pelo fato de ter integrado o pacote das 10 Medidas Contra a Corrupção, desenvolvido no âmbito do Ministério Público Federal e apoiado por parte da população brasileira. É o que se fará na subseção seguinte.

\subsection{As 10 Medidas Contra a Corrupção e o teste de integridade no setor público}

Em março de 2015, o Ministério Público Federal, valendo-se do trabalho desenvolvido por comissão constituída pelo então procurador-geral da República, lançou a campanha 10 Medidas Contra a Corrupção, buscando, em tese, aperfeiçoar a prevenção e a repressão à corrupção e promover a instituição de mecanismos que permitissem a recuperação do lucro derivado do crime, por meio da apresentação de dezenove anteprojetos de lei e um anteprojeto de emenda à Constituição à sociedade brasileira a fim de que, uma vez atendidos os requisitos previstos na legislação, fossem encaminhados ao Congresso Nacional como projetos de lei e de emenda à Constituição de iniciativa popular, sob a inspiração do exemplo exitoso da Lei da Ficha Limpa.

No mês de março de 2016, os anteprojetos que compõem as 10 Medidas Contra a Corrupção foram entregues à Câmara de Deputados, acompanhados da assinatura de mais de dois milhões de cidadãos. As 10 Medidas Contra a Corrupção se tornaram o Projeto de Lei (PL) 4.850/2016, cujo relatório aprovado na Comissão Especial, mantendo em grande parte o trabalho entregue pela população ao parlamento, foi severamente desfigurado pelo Plenário da 
Câmara no dia 30 de novembro de 2016, de onde rumou para o Senado Federal, casa na qual recebeu o número de PLC 80/2016.

Posteriormente, houve decisão do Supremo Tribunal Federal (STF) determinando o retorno do Projeto de Lei à Câmara dos Deputados, o que foi cumprido pelos presidentes da Câmara e do Senado Federal e resultou na extinção do processo no STF. Em seguida, após diligências adotadas pela Câmara em atendimento à decisão do STF, houve o reenvio do PL para o Senado, onde recebeu o número de PLC 27/2017. Em 26 de junho de 2019, o Senado aprovou o PLC 27/2017 e remeteu o texto para a Câmara dos Deputados ${ }^{33}$.

Inserida na Medida 1 (Investimento em Prevenção) está a proposta de criação do teste de integridade de agentes públicos, formada por onze artigos. Trata-se, no dizer do art. $3^{\circ}$ do anteprojeto, da simulação de situações sem o conhecimento do agente público, com o objetivo de testar sua conduta moral e predisposição para cometer ilícitos contra a Administração Pública. Prevê-se, no art. $9^{\circ}$, a necessidade de autorização judicial para que os testes de integridade sejam realizados pelo Ministério Público ou pelos órgãos policiais em investigações criminais ou que digam respeito à prática de atos de improbidade.

As medidas apresentadas pelo MPF e encampadas por mais de dois milhões de brasileiros foram e têm sido alvo de críticas diversas por professores, juristas e congressistas. E parte dessas críticas recai justamente sobre o teste de integridade, que tem encontrado resistência a sua aceitação, do que resultou a rejeição dessa ferramenta de combate e prevenção à corrupção ainda na Comissão Especial instituída na Câmara dos Deputados para analisar o PL 4.850/2016

A título ilustrativo, durante as audiências ocorridas na Comissão Especial, o presidente do Sindicato Nacional dos Auditores Fiscais da Receita Federal (Sindifisco Nacional) disse acreditar que o teste de integridade viola o princípio constitucional da presunção de inocência ${ }^{35}$; o delegado de Polícia Federal Marcio Anselmo, além de não concordar com a medida, afirmou

${ }^{33}$ MIGALHAS. Senado aprova projeto das "10 medidas contra a corrupção". 27 jun. 2019. Disponível em: https: / / www.migalhas.com.br/Quentes/17,Ml305234,11049-

Senado+aprova+projeto+das+10+medidas+contra+corrupcao. Acesso em: 18 jul. 2019.

34 CÂMARA NOTÍCIAS. Comissão exclui teste de integridade do projeto anticorrupção. 24 nov. 2016. Disponível em: http://www2.camara.leg.br/camaranoticias/noticias/DIREITO-E-JUSTICA/519953COMISSAO-EXCLUI-TESTE-DE-INTEGRIDADE-DO-PROJETO-ANTICORRUPCAO.html. Acesso em: 23 mar. 2017.

35 CÂMARA NOTÍCIAS. Teste de integridade para servidor público recebe críticas em comissão especial. 9 set. 2016. Disponível em: https://wWw2.camara.leg.br/camaranoticias/noticias/ADMINISTRACAOPUBLICA/516017-TESTE-DE-INTEGRIDADE-PARA-SERVIDOR-RECEBE-CRITICAS-EM-COMISSAO-ESPECIAL.html. Acesso em: 18 jul. 2017. 
que ela viola tratados internacionais ${ }^{36}$; e o diretor jurídico da Federação Nacional dos Policiais Rodoviários Federais (FENAPRF) Jesus Castro Caamano, por sua vez, afirmou que a proposta permite forjar um flagrante, o que, segundo ele, contraria decisões do Supremo Tribunal Federal $^{37}$. Foi por causa dessa forte oposição ao teste de integridade que ele nem sequer foi levado ao Plenário da Câmara dos Deputados.

O teste de integridade também está sendo tratado, na Câmara dos Deputados, pelos PLs 3928/15, do deputado federal Indio da Costa (PSD-RJ), e 3969/15, do deputado Miro Teixeira (Rede-RJ), os quais foram rejeitados no mês de junho de 2017 pela Comissão de Segurança Pública e Combate ao Crime Organizado da Câmara dos Deputados e aguardam análise de outras comissões.

O teste de integridade surgiu em departamentos de polícia dos Estados Unidos da América, especialmente em Nova York, na década de 70, difundindo-se principalmente nos países da common law, como o Reino Unido e a Austrália. Em Hong Kong, além da polícia, o teste de integridade também é aplicado em todo o setor público ${ }^{38}$, amplitude que as 10 Medidas pretendiam lhe impor.

Mais recentemente, países europeus de tradição jurídica diversa da common law e com alto grau de corrupção pública também têm tido sucesso em implantar testes de integridade, a exemplo da Geórgia e da Moldávia ${ }^{39}$. A meta tem sido, em tais casos, aprimorar a governança no serviço público, minando a corrupção.

O êxito de sua implantação em países de tradições jurídicas distintas tem levado diversos organismos e atores internacionais a recomendar a aplicação dos testes de integridade como ferramenta de combate à corrupção, como o fizeram a Organização para a Cooperação e

\footnotetext{
${ }^{36}$ CONJUR. Delegado da PF critica teste de integridade e validação de prova ilícita. 18 out. 2016. Disponível em: https://www.conjur.com.br/2016-out-18/delegado-pf-critica-teste-integridade-uso-provailicita. Acesso em: 18 jul. 2017.

37 CÂMARA NOTÍCIAS. Relator sugere mudança em teste de integridade proposto no projeto de combate à corrupção. $162016 . \quad$ ago. 20 Disponível https://www2.camara.leg.br/camaranoticias/noticias/ADMINISTRACAO-PUBLICA/514803-RELATORSUGERE-MUDANCA-EM-TESTE-DE-INTEGRIDADE-PROPOSTO-NO-PROJETO-DE-COMBATE-A-CORRUPCAO.html. Acesso em: 17 jul 2017.

38 ASSOCIACC̃̃O NACIONAL DOS PROCURADORES DA REPÚBLICA (ANPR). Nota Técnica PRESI/ANPR/JR $N^{\circ} 017 / 2016$. Disponível

em: http://anpr.org.br/assets/uploads/files/noticias/2016/09_Setembro/NT_MEDIDA1_testedeintegridade.pdf . Acesso em: 28 out. 2016. p. 10.

${ }^{39}$ COUNCIL OF EUROPE. Integrity Testing - Aspects of Implementation Drafted by Dr. Tilman Hoppe, LL.M., Project Long-Term Adviser 19 December 2014.
} 
Desenvolvimento Econômico - OCDE, o Conselho da Europa, o Escritório das Nações Unidas sobre Drogas e Crime, o Banco Mundial e a Transparência Internacional ${ }^{40}$.

Em síntese, o teste de integridade aplicado no setor público consiste na simulação de situação real em que se cria uma oportunidade ao agente público testado de agir de forma ilícita, para aferir como ele se porta e, se for o caso, responsabilizá-lo. Basicamente, existem dois tipos de teste de integridade, ambos previstos no anteprojeto convertido no PL 4.850/2016: o aleatório e o dirigido.

O teste de integridade aleatório tem como alvo agentes públicos escolhidos ao acaso, em um determinado segmento do serviço público. Normalmente os agentes públicos estão conscientes de que podem ser submetidos a testes de integridade aleatórios, o que desencoraja a prática de atos ilícitos, pois o agente não saberá se se tratará de uma real possibilidade de receber propina ou de um teste a que está sendo submetido, por exemplo.

0 teste de integridade dirigido, por sua vez, é direcionado a um agente público específico, quando há informações de que ele praticou atos de corrupção ou outros ilícitos. Essas informações podem ser fornecidas por colegas de trabalho ou cidadãos, ou ter por base a existência de patrimônio incompatível com a renda lícita auferida.

As críticas à instituição do teste de integridade na Administração Pública foram as mais diversas. Streck ${ }^{41}$ etiquetou-o como uma espécie de "eugenia cívica”, comparando-o ao filme Minority Report, em que o Estado consegue debelar homicídios por intermédio de uma divisão pré-crime, na qual se visualiza o crime antes de ele acontecer. Em debate na Câmara dos Deputados, o presidente do Fórum Nacional Permanente de Carreiras Típicas de Estado considerou absurda a adoção da medida ${ }^{42}$. Houve mesmo quem utilizasse o Teorema de Bayes para rejeitar a eficácia do teste de integridade ${ }^{43}$.

40 ASSOCIAÇÃO NACIONAL DOS PROCURADORES DA REPÚBLICA (ANPR). Nota Técnica PRESI/ANPR/JR $\mathrm{N}^{\circ} 017 / 2016$. Disponível

em: http://anpr.org.br/assets/uploads/files/noticias/2016/09_Setembro/NT_MEDIDA1_testedeintegridade.pdf . Acesso em: 28 out. 2016. p. 5-9.

41 STRECK, Lenio. O pacote anticorrupção do Ministério Público e o fator Minority Report. Consultor Jurídico, 3 mar. 2016. Disponível em: http://www.conjur.com.br/2016-mar-03/senso-incomum-pacoteanticorrupcao-mpf-fator-minority-report. Acesso em: 28 ago. 2016.

42 RADIOAGÊNCIA. Associação que representa carreiras de estado critica testes de integridade. 15 ago. 2016. Disponível em: http:// www2.camara.leg.br/camaranoticias/radio/materias/RADIOAGENCIA/514792ASSOCIACAO-QUE-REPRESENTA-CARREIRAS-DE-ESTADO-CRITICA-TESTES-DE-INTEGRIDADE.html. Acesso em: 5 mai. 2017.

43 MILIONI, Armando Zeferino; OLIVEIRA, Adjame Alexandre Gonçalves. Bayes contra o teste de integridade. Jota, 3 set. 2016. Disponível em: https://www.jota.info/especiais/bayes-contra-o-teste-deintegridade-03092016. Acesso: 12 nov. 2016. 
No entanto, as críticas dirigidas ao teste de integridade no setor público não se prestam para rechaçar o teste de integridade no setor privado, que, diferentemente de seu congênere público, já é aplicado há algum tempo no Brasil sem maiores sobressaltos.

\subsection{0 teste de integridade no setor privado}

No setor privado, o teste de integridade vem sendo adotado no Brasil há mais de uma década. Em reportagem de 2005, o portal Terra anunciava a chegada ao mercado nacional de um teste de integridade online oferecido pela consultoria ProsetsBrasil ${ }^{44}$.

Somente o grupo Endeavor, instituição de apoio ao empreendedorismo, utiliza o teste de integridade desde 2007 na etapa final da seleção dos novos empresários que farão parte da rede por ele coordenada ${ }^{45}$.

Não existe um padrão para a aplicação do teste de integridade no setor privado. Geralmente, ele é aplicado no momento que antecede a contratação, em etapa pré-contratual, mas também há relatos de sua utilização antes da nomeação para cargos de gerência ou diretoria, a exemplo do grupo Randon, que produz equipamentos para o transporte rodoviário. 0 grupo Randon inseriu dentro do seu programa de compliance o teste de integridade para gerentes-executivos e diretores ${ }^{46}$.

$\mathrm{Na}$ rede de restaurantes Pobre Juan, que possui onze unidades no país, o candidato a uma vaga de emprego passa pelo teste denominado Potencial de Integridade Resiliente como fase obrigatória do processo de seleção, o qual foi criado e é oferecido pela S2 Consultoria. Para a empresa do ramo alimentício, o teste de integridade funciona como um guia aos gestores sobre as melhores práticas de orientação e acompanhamento no dia a dia nas operações dos empregados contratados ${ }^{47}$. Isso significa que o teste de integridade não possui um caráter meramente reativo, mas também educativo, na medida em que permite à firma buscar capacitar

44 TERRA. Teste online detecta nível de ética no trabalho. Terra, 26 out. 2005. Disponível em: http://tecnologia.terra.com.br/noticias/0,,0l726198-El15608,00-

Teste+online+detecta+nivel+de+etica+no+trabalho.html. Acesso em: 12 mar. 2018.

45 NOMURA, Leandro. Você passaria no 'teste de honestidade'? Folha de São Paulo, 12 nov. 2017. Disponível em: https://www1.folha.uol.com.br/sobretudo/carreiras/2017/11/1934445-voce-passaria-noteste-de-honestidade.shtml?loggedpaywall. Acesso em: 19 mar. 2018.

${ }^{46}$ NOMURA, Leandro. Você passaria no 'teste de honestidade'? Folha de São Paulo, 12 nov. 2017. Disponível em: https://www1.folha.uol.com.br/sobretudo/carreiras/2017/11/1934445-voce-passaria-no-teste-dehonestidade.shtml?loggedpaywall. Acesso em: 19 mar. 2018.

47 SANTOS, Renato. Teste de integridade: como mapear o DNA ético do seu futuro colaborador? Endeavor Brasil, 14 mar. 2017. Disponível em: https://endeavor.org.br/teste-de-integridade-como-mapear-o-dnaetico-seu-futuro-colaborador/. Acesso em: 19 mar. 2018. 
o empregado testado para a boa governança e ética, proporcionando um plano de desenvolvimento que ajude o participante na conscientização e reflexão de comportamentos que devem ser revistos ${ }^{48}$.

$\mathrm{Na}$ consultoria EY, nova marca da Ernst \& Young, desde 2008 a diretoria de compliance aplica questionários para aferir aspectos de ética e integridade corporativa nos candidatos a vagas em sua equipe ${ }^{49}$.

Junges $^{50}$ relata que, somente do final de 2014 até março de 2017, cerca de três mil profissionais brasileiros de escalões diversos passaram pelo teste de integridade com apenas uma das várias consultoras que oferecem o teste no mercado. 0 número parece grande, mas ainda é diminuto se comparado com experiências de outros países.

Nos Estados Unidos da América, onde a implementação de programas de compliance é disseminada há décadas por influência do FCPA, estudo promovido pelo Office of Technology Assessment - OTA do Congresso estadunidense, datado de 1990, estimou entre cinco e seis mil as companhias que utilizavam testes de integridade em candidatos a um emprego ${ }^{51}$. Para as empresas com mais de cem empregados nos Estados Unidos, a estimativa é que três quartos se valham de avaliações psicológicas para contratação a fim de analisar traços de competência, ética e inteligência emocional ${ }^{52}$. $E$ não é por menos: no início da década de 90 , estimava-se em 40 bilhões de dólares o prejuízo causado aos negócios por apenas onze tipos de crimes não violentos (incluindo subtração de bens da empresa, vandalismo e corrupção) ${ }^{53}$.

Mas, afinal, no que consiste o teste de integridade no setor privado? O Office of Technology Assessment definiu os testes de integridade como:

\footnotetext{
48 SANTOS, Renato. Testes de integridade devem ter caráter educativo, e não julgador. 0 Estado de São Paulo, 31 mar. 2018. Disponível em: https://politica.estadao.com.br/blogs/fausto-macedo/testes-deintegridade-devem-ter-carater-educativo-e-nao-julgador $/$. Acesso em: 3 mai. 2018.

49 SARAIVA, Jacilio. Novos tipos de testes psicológicos avaliam postura ética e preconceitos. Valor Econômico, 2 out. 2014. Disponível em: http://www.valor.com.br/carreira/3718978/novos-tipos-detestes-psicologicos-avaliam-postura-etica-e-preconceitos. Acesso em: 9 jun. 2018.

50 JUNGES, Cíntia. Após Lava Jato, teste de integridade ganha espaço como critério de seleção. Gazeta do Povo, 31 mar. 2017. Disponível em: https://www.gazetadopovo.com.br/economia/pos-e-carreira/aposlava-jato-teste-de-integridade-ganha-espaco-como-criterio-de-selecao-cahhjopjdnw7ombm3z8noojhj/. Acesso em: 15 abr. 2018.

51 OFFICE OF TECHNOLOGY ASSESSMENT (OTA), U.S. CONGRESS. The Use of Integrity Tests for PreEmployment Screening. Sep. 1990, p. 1. Disponível em: http://ota.fas.org/reports/9042.pdf. Acesso em: 20 nov. 2017.

52 LEBOWITZ, Shana. 6 sample questions employers ask to assess your personality. Business Insider, 16 jul. 2015. Disponível em: http://www.businessinsider.com/sample-questions-on-personality-tests-2015-7. Acesso em: 9 jun. 2018.

53 OFFICE OF TECHNOLOGY ASSESSMENT (OTA), U.S. CONGRESS. The Use of Integrity Tests for PreEmployment Screening. Sep. 1990. p. 20. Disponível em: http://ota.fas.org/reports/9042.pdf. Acesso em: 20 nov. 2017.
} 
Testes escritos destinados a identificar indivíduos que se candidatam a empregos nos quais são altamente propensos a subtrair dinheiro ou coisas do trabalho, ou que tendem a se envolver em comportamento de natureza mais "contraproducente" [...] quase todos os testes escritos administrados em candidatos a emprego em algum estágio da triagem e do processo de seleção. ${ }^{54}$

Obviamente, a definição do OTA, por datar de 1990, destaca o caráter escrito do teste de integridade no setor privado, embora, como visto, atualmente parcela considerável das consultorias se utilize de softwares e aplique os testes online.

Se é certo que os testes de integridade passam longe de ser perfeitos, psicólogos norteamericanos reconhecidos na área de atuação respectiva os consideram melhores do que qualquer alternativa disponível para avaliar e selecionar candidatos honestos a empregos ${ }^{55}$.

Embora a adoção do teste de integridade no setor privado seja mais frequente durante a etapa de seleção de candidatos a vagas de empregos, já há quem forneça o serviço de aplicação de testes de integridade periódicos, direcionados a um setor específico ou mesmo a um determinado funcionário. É o caso da empresa Integrity Meter, que atua no mercado oferecendo tanto o teste de integridade de triagem pré-contratação, como o teste periódico, este último destinado "a oferecer às organizações a opção de obter ocasionalmente um quadro preciso de tudo o que está acontecendo na empresa, descobrindo enganos dos funcionários, evitando perdas e uma longa lista de outros possíveis problemas"56.

O extenso rol de empresas e consultorias aplicadoras do teste de integridade, de empresas contratantes e de pessoas a ele submetidas, tanto aqui como no exterior, corrobora a assertiva da introdução deste artigo, segundo a qual o teste de integridade já é uma realidade no setor privado. Para além dessa constatação, convém investigar se os programas de compliance necessariamente devem prever a implementação do teste de integridade. Esse é o intuito da próxima seção.

54 OFFICE OF TECHNOLOGY ASSESSMENT (OTA), U.S. CONGRESS. The Use of Integrity Tests for PreEmployment Screening. Sep. 1990. p. 1. Disponível em: http://ota.fas.org/reports/9042.pdf. Acesso em: 20 nov. 2017. Tradução nossa. No original, lê-se: "Written tests designed to identify individuals applying for work in such jobs who have relatively high propensities to steal money or property on the job, or who are likely to engage in behavior of a more generally 'counterproductive' nature [...] almost all paper-andpencil instruments, administred to job applicants at some stage of the screening and selection process."

55 OFFICE OF TECHNOLOGY ASSESSMENT (OTA), U.S. CONGRESS. The Use of Integrity Tests for PreEmployment Screening. Sep. 1990. p. 9. Disponível em: http://ota.fas.org/reports/9042.pdf. Acesso em: 20 nov. 2017.

56 INTEGRITY METER. Teste períodico. Integrity Meter, recruit to perfection. Disponível em: http://www.integritymeter.com/pt-br/periodic. Acesso em: 20 mai. 2018. 


\section{OS PROGRAMAS DE COMPLIANCE E O TESTE DE INTEGRIDADE}

Na subseção 1.3, demonstrou-se que a legislação brasileira ainda é bastante tímida ao tratar dos programas de compliance, inexistindo dever legal ou estímulos jurídicos substanciosos para que as companhias brasileiras ou submetidas ao direito nacional desenvolvam um programa de conformidade eficaz. O único incentivo legal consiste na possibilidade de redução da multa administrativa da Lei 12.846/2013.

Viu-se, contudo, que além de a existência de programas de compliance ser imperativo para empresas brasileiras que transacionem sob a regência do FPCA norte-americano ou do UKBA britânico, o mercado vem se tornando cada vez mais exigente em relação aos programas de integridade, do que é exemplo digno de nota a classificação da B3 das empresas listadas na categoria Novo Mercado.

Por tais motivos, é razoável admitir que empresas de médio e grande porte disponham de programas de compliance, ou ao menos que cada vez mais empresas de maior envergadura passem a adotar programas de integridade e conformidade.

Partindo desse pressuposto, investiga-se se há normas incentivando - implícita ou explicitamente - a inserção de testes de integridade nos programas de compliance, ou se tal medida é conveniente a despeito da eventual inexistência de tal estímulo. Isso porque, de acordo com Beck ${ }^{57}$, a estruturação organizacional do compliance está amparada em sete pilares, um dos quais corresponde à "adoção das medidas necessárias para a contenção dos riscos (identificados os riscos, deve ser selecionada a pessoa adequada para cada posto de trabalho e adotado um programa de cumprimento onde constem todas as medidas necessárias para a minimização de riscos)".

Para tanto, será feito um breve apanhado da legislação estrangeira e nacional e de normas procedimentais.

\subsection{0 teste de integridade e o FCPA}

Nos Estados Unidos, o Department of Justice (DOJ) criou o documento intitulado Principles of Federal Prosecution of Business Organizations, que integra o United States

${ }^{57}$ BECK, Francis Rafael. A dupla face do criminal compliance: da expectativa de afastamento e mitigação da responsabilidade penal à possibilidade de incremento punitivo. In: Compliance no ordenamento jurídico brasileiro. DUTRA, Lincoln Zub (org.). Curitiba: Juruá, 2018. p. 77. 
Attorney's Manual - USAM, a fim de possibilitar, dentre outras coisas, a análise de um programa de compliance efetivo, e não apenas “de papel”.

Segundo o Principles of Federal Prosecution of Business Organizations, os promotores americanos devem buscar:

[...] determinar se o programa de compliance da empresa é meramente um "programa de papel" ou se ele foi produzido, implementado, revisto e revisado apropriadamente, de uma maneira efetiva. Além disso, os promotores devem determinar se a empresa disponibilizou uma equipe suficiente para auditar, documentar, analisar e utilizar os resultados do esforço de conformidade da empresa. ${ }^{58}$

Por sua vez, o United States Federal Sentencing Guideline prevê um conjunto de medidas que devem ser contempladas nos programas de compliance para que ele possa ser considerado efetivo e, consequentemente, possa levar à redução das penas fixadas em processos que versam sobre o cometimento de crimes de diversas naturezas ${ }^{59}$. Dentre tais providências, determina o normativo que:

A sociedade empresária deve usar meios razoáveis para escolher pessoas para exercer cargos de chefia que ninguém da empresa sabia, ou devesse saber por força do dever de diligência, ter envolvimento com atividades ilícitas ou outras condutas incompatíveis com um programa efetivo de compliance. ${ }^{60}$

Pode-se afirmar, desse modo, que a forma como o FCPA deve ser manejado pelos promotores e juízes americanos ao analisar os programas de compliance de empresas envolvidas em atividades ilícitas respalda a aplicação do teste de integridade no âmbito corporativo, ainda que não haja menção expressa a tal mecanismo de compliance, visto que o teste de integridade

58 OFFICE OF THE UNITED STATES ATTORNEYS. United States Attorney's Manual - USAM. Disponível em: https://www.justice.gov/usam/usam-9-28000-principles-federal-prosecution-business-organizations\#9-

28.800. Acesso em: 3 mai. 2018. Tradução nossa. No original, lê-se: “[...] to determine whether a corporation's compliance program is merely a "paper program" or whether it was designed, implemented, reviewed, and revised, as appropriate, in an effective manner. In addition, prosecutors should determine whether the corporation has provided for a staff sufficient to audit, document, analyze, and utilize the results of the corporation's compliance efforts".

59 CASTRO, Marina Grimaldi. O programa de compliance corporativo. In: Compliance no ordenamento jurídico brasileiro. DUTRA, Lincoln Zub (org.). Curitiba: Juruá, 2018. p. 166.

60 UNITED STATES SENTENCING COMMISSION - USSC. Guidelines Manual. Washington, 1 nov. 2016. Disponível em: https://www.ussc.gov/sites/default/files/pdf/guidelines-manual/2016/GLMFull.pdf. Acesso em: 9 jun. 2018. p. 534. Tradução nossa. No original, lê-se: “The organization shall use reasonable efforts not to include within the substantial authority personnel of the organization any individual whom the organization knew, or should have known through the exercise of due diligence, has engaged in illegal activities or other conduct inconsistent with an effective compliance and ethics program." 
consiste num meio razoável para promover ou contratar colaboradores para cargos de maior responsabilidade, contribuindo para uma decisão mais embasada da área de recursos humanos, conselho diretor ou quem quer que seja o responsável por contratar ou escolher alguém para um cargo de diretor, gerente ou chefe.

\subsection{0 teste de integridade e o UKBA}

O United Kingdom Bribery Act (UKBA) é uma das mais arrojadas leis anticorrupção da atualidade, conforme pontuado precedentemente, em razão de criminalizar a mera conduta de falhar na prevenção de corrupção ${ }^{61}$, na Seção 7(1).

Porém, a despeito de transferir ao particular todo o ônus de prevenir a prática de atos de corrupção, tornando-o responsável por desenhar, implementar, aplicar e avaliar sua própria regulamentação ${ }^{62}$, a Seção 7(2) do UKBA consigna constituir uma defesa para uma empresa envolvida em atos de corrupção a comprovação de que ela adotava "procedimentos adequados" para prevenir tais práticas.

Com a finalidade de atender a imposição da Seção 9 do UKBA, o governo britânico editou o "The Bribery Act 2010 Guidance”, informando quais procedimentos devem ser adotados pelas sociedades empresárias para não serem responsabilizadas nos termos da Seção 7(1).

0 “The Bribery Act 2010 Guidance” prevê seis princípios que devem ser seguidos pelas empresas para se utilizar da defesa da Seção 7(2): Princípio 1 - proporcionalidade nos procedimentos a serem observados; Princípio 2 - compromisso da cúpula da empresa; Princípio 3 - avaliação de riscos; Princípio 4 - diligências prévias; Princípio 5 - comunicação e treinamento; Princípio 6 - monitoração e revisão ${ }^{63}$.

Ao tratar do Princípio 4, o “ The Bribery Act 2010 Guidance” dispõe no item 4.6 que:

\footnotetext{
${ }^{61}$ CARVALHO, Paulo Roberto Galvão de. Legislação anticorrupção no mundo: análise comparativa entre a Lei Anticorrupção brasileira, o Foreign Corrupt Practices Act norte-americano e o Bribery Act do Reino Unido. In: Lei Anticorrupção. QUEIROZ, Ronaldo Pinheiro de; SOUZA, Jorge Munhós (org.). Salvador: Juspodivm, 2015. p. 53.

62 CARVALHO, Paulo Roberto Galvão de. Legislação anticorrupção no mundo: análise comparativa entre a Lei Anticorrupção brasileira, o Foreign Corrupt Practices Act norte-americano e o Bribery Act do Reino Unido. In: Lei Anticorrupção. QUEIROZ, Ronaldo Pinheiro de; SOUZA, Jorge Munhós (org.). Salvador: Juspodivm, 2015. p. 53.

63 MINISTRY OF JUSTICE. The Bribery Act 2010 Guidance. 11 fev. 2012. Disponível em: https://www.gov.uk/government/uploads/system/uploads/attachment_data/file/181762/bribery-act2010-guidance.pdf. Acesso em: 8 abr. 2018. p. 20-31.
} 
Presume-se que os empregados de uma sociedade empresária sejam pessoas "engajadas" com a empresa para os propósitos do Bribery Act. A sociedade empresária pode desejar, portanto, incorporar em seus procedimentos de recrutamento e recursos humanos um nível apropriado de devida diligência (due diligence) para mitigar os riscos de corrupção a que estão submetidos os empregados, o que é proporcional ao risco associado ao cargo em questão. ${ }^{64}$

Mais uma vez, verifica-se o respaldo suficiente na legislação anticorrupção para a implantação de testes de integridade no setor privado, no caso, dentro dos programas de compliance que o Bribery Act exige para afastar a responsabilização penal pela conduta de falhar na prevenção de atos de corrupção.

\subsection{0 teste de integridade e a norma ABNT NBR ISO 37001}

A International Organization for Standardization (ISO) é uma organização não governamental que congrega entidades de padronização de todo o mundo em mais de 160 países $^{65}$. Em 2014, uma equipe da ISO composta por especialistas de trinta e sete países, após quatro anos de debates, elaborou a ISO 37001, intitulada Anti-bribery management systems ${ }^{66}$.

Para reconhecimento da norma no Brasil como oficial, a Associação Brasileira de Normas Técnicas (ABNT), por meio de uma Comissão de Estudo Especial Antissuborno, publicou, em março de 2017, a ABNT NBR ISO 37001, reproduzindo a norma internacional ${ }^{67}$.

Na introdução da norma ABNT NBR ISO 37001, registra-se que a lei não é suficiente para resolver o problema da corrupção, daí surgindo a necessidade de as organizações contribuírem proativamente para o combate ao suborno. A ISO 37001, assim, tem por finalidade fornecer um

64 MINISTRY OF JUSTICE. The Bribery Act 2010 Guidance. 11 fev. 2012. Disponível em: https://www.gov.uk/government/uploads/system/uploads/attachment_data/file/181762/bribery-act2010-guidance.pdf. Acesso em: 8 abr. 2018. p. 28. Tradução nossa. No original, lê-se: "A commercial organisation's employees are presumed to be persons 'associated' with the organisation for the purposes of the Bribery Act. The organisation may wish, therefore, to incorporate in its recruitment and human resources procedures an appropriate level of due diligence to mitigate the risks of bribery being undertaken by employees which is proportionate to the risk associated with the post in question."

${ }^{65}$ ENCYCLOPFEDIA BRITANNICA. International Organization for Standardization. 2018. Disponível em: https://www.britannica.com/topic/International-Organization-for-Standardization. Acesso em: 9 jun. 2018.

66 RAMOS, Raeclara Drummond. Norma ABNT NBR ISO 37001: Sistemas de Gestão Antissuborno. In: Compliance como instrumento de combate à corrupção. MARQUES, Jader; PORTO, Vinicius (org.). Porto Alegre: Livraria do Advogado, 2017. p. 129.

67 RAMOS, Raeclara Drummond. Norma ABNT NBR ISO 37001: Sistemas de Gestão Antissuborno. In: Compliance como instrumento de combate à corrupção. MARQUES, Jader; PORTO, Vinicius (org.). Porto Alegre: Livraria do Advogado, 2017. p. 130. 
sistema de gestão antissuborno por intermédio de uma liderança comprometida no estabelecimento de uma cultura de integridade, transparência, abertura e compliance ${ }^{68}$.

A norma ABNT NBR ISO 37001 é composta por dez tópicos, divididos em subtópicos, e por um Anexo A contendo orientações ilustrativas num total de vinte e dois itens.

De acordo com Ramos ${ }^{69}$, as medidas de aplicação do sistema antissuborno devem englobar a totalidade das operações da empresa, inclusive a contratação de funcionários, atividade que envolve uma série de riscos e pode comprometer a integridade ética da empresa, prejudicando a política da organização.

Abordando os procedimentos de contratação de pessoal, o item A.8 do Anexo A da norma ABNT NBR ISO 37001 esclarece:
A.8.1 Due diligence em pessoas
Ao proceder à due diligence em pessoas, antes de admiti-las, a organização, dependendo das funções propostas e dos correspondentes riscos de suborno, pode tomar ações como:
a) discutir a política antissuborno da organização com potencial candidato em uma entrevista e formar uma opinião se o pessoal parece entender e aceitar a importância do compliance;
b) adotar medidas razoáveis, a fim de verificar se as qualificações do potencial candidato são precisas;
d) adotar medidas razoáveis para determinar se o potencial candidato se envolveu com subornos; ${ }^{70}$

De novo, embora não haja referência expressa ao teste de integridade, pode-se extrair do item A.8.1 do Anexo A da norma ABNT NBR ISO 37001 a possibilidade de aplicá-lo na etapa pré-contratual. $O$ teste de integridade pode ser utilizado para auxiliar na obtenção do perfil do candidato a uma determinada função; verificar se as informações prestadas pelo candidato são precisas, isto é, convergem com o seu teste de integridade; e pode ser utilizado para identificar eventual envolvimento pretérito com subornos.

Encampando o mesmo entendimento, $\operatorname{Ramos}^{71}$ sustenta que a prevenção contra o oferecimento de suborno por um funcionário em nome da organização é feita, muitas vezes,

68 ASSOCIAÇÃO BRASILEIRA DE NORMAS TÉCNICAS (ABNT). ABNT NBR ISO 37001. Sistemas de gestão antissuborno. Rio de Janeiro: 2017. p. viii.

69 RAMOS, Raeclara Drummond. Norma ABNT NBR ISO 37001: Sistemas de Gestão Antissuborno. In: Compliance como instrumento de combate à corrupção. MARQUES, Jader; PORTO, Vinicius (org.). Porto Alegre: Livraria do Advogado, 2017. p. 133.

70 ASSOCIAÇÃO BRASILEIRA DE NORMAS TÉCNICAS (ABNT). ABNT NBR ISO 37001. Sistemas de gestão antissuborno. Rio de Janeiro: 2017. p. 32. 
através dos controles e procedimentos na contratação de pessoal, onde se encaixa com precisão o teste de integridade.

A despeito de não configurar norma jurídica, a norma ABNT NBR ISO 37001 pode ser utilizada, portanto, como anteparo à adoção dos testes de integridade nos programas de compliance, por ser fruto do trabalho de experts e representar um padrão a ser seguido pelo mercado.

\subsection{0 teste de integridade, a Lei $12.846 / 2013$ e o Decreto $8.420 / 2015$}

$\mathrm{Na}$ subseção 1.3, discorreu-se sobre a Lei 12.846/2013, ou Lei Anticorrupção Empresarial (LAE), e pontuou-se que ela não prevê, satisfatoriamente, estímulos para que as sociedades empresariais adotem programas de compliance.

Em rigor, "a existência de mecanismos e procedimentos internos de integridade, auditoria e incentivo à denúncia de irregularidades e a aplicação efetiva de códigos de ética e de conduta no âmbito da pessoa jurídica" (LAE, art. $7^{\circ}$, VIII) oferece, como dito, uma única vantagem ao agente a quem for imputado um dos atos lesivos previstos na Lei 12.846/2013: a possibilidade de redução da multa administrativa.

A LAE, contudo, não traz parâmetros que permitam avaliar se os mecanismos de integridade e compliance são suficientes a fazer incidir a diminuição da multa administrativa, delegando-os a regulamento cuja expedição foi atribuída ao Poder Executivo Federal, nos termos do art. $7^{\circ}$, parágrafo único, da mesma lei.

Atendendo à disposição do art. $7^{\circ}$, parágrafo único, da Lei Anticorrupção Empresarial, a Presidência da República editou o Decreto $8.420^{72}$, de 18 de março de 2015, com o fito de regulamentar a responsabilização objetiva administrativa de pessoas jurídicas pela prática de atos contra a administração pública, nacional ou estrangeira, de que trata a Lei 12.846/2013.

De acordo com o art. $4^{\circ}, 5^{\circ}$, do Decreto $8.420 / 2015$, se a pessoa jurídica que estiver sendo alvo de processo administrativo de responsabilização apresentar como defesa informações

71 RAMOS, Raeclara Drummond. Norma ABNT NBR ISO 37001: Sistemas de Gestão Antissuborno. In: Compliance como instrumento de combate à corrupção. MARQUES, Jader; PORTO, Vinicius (org.). Porto Alegre: Livraria do Advogado, 2017. p. 136.

72 BRASIL. Decreto $n^{\circ} 8.420$, de 18 de março de 2015. Regulamenta a Lei $n^{\circ} 12.846$, de $1^{\circ}$ de agosto de 2013, que dispõe sobre a responsabilização administrativa de pessoas jurídicas pela prática de atos contra a administração pública, nacional ou estrangeira e dá outras providências. In: Diário Oficial da República Federativa do Brasil, Brasília, DF, 19 mar. 2015. Disponível em: http://www.planalto.gov.br/ccivil_03/_Ato2015-2018/2015/Decreto/D8420.htm. Acesso em: $10 \mathrm{mar}$. 2018. 
e documentos referentes à existência e ao funcionamento de programa de integridade, a comissão processante deverá examiná-lo segundo os parâmetros indicados no Capítulo IV do Decreto.

O Capítulo IV do Decreto $8.420 / 2015$, a seu turno, é composto pelos arts. 41 , no qual conceitua o programa de integridade, e 42, em que elenca dezesseis incisos fixando os parâmetros para avaliação do programa de integridade, este último contendo, ainda, cinco parágrafos.

Castro $^{73}$ anota que, além de ter contemplado praticamente os mesmos itens constantes no United States Sentencing Commission Guidelines Manual, o decreto brasileiro foi além, tendo em vista que dispõe sobre a aplicação do programa de compliance aos terceiros que se relacionam com a pessoa jurídica e determina que os registros contábeis devem ser dotados de precisão.

Interessam-nos, em particular, os seguintes incisos do art. 42 do Decreto 8.420/2015:

Art. 42. Para fins do disposto no $\S 4^{\circ}$ do art. $5^{\circ}$, o programa de integridade será avaliado, quanto a sua existência e aplicação, de acordo com os seguintes parâmetros:

II - padrões de conduta, código de ética, políticas e procedimentos de integridade, aplicáveis a todos os empregados e administradores, independentemente de cargo ou função exercidos;

V - análise periódica de riscos para realizar adaptações necessárias ao programa de integridade;

XIII - diligências apropriadas para contratação e, conforme o caso, supervisão, de terceiros, tais como, fornecedores, prestadores de serviço, agentes intermediários e associados;

A mesma construção feita em relação ao FCPA, ao UKBA e à norma ABNT NBR ISO 37001 é cabível aqui, no sentido de se extrair dos dispositivos transcritos a fundamentação suficiente para a adoção do teste de integridade nos programas de compliance.

A propósito, além de vir sendo utilizado no mundo corporativo de forma "avulsa" ou sob demanda, para situações específicas, o teste de integridade já compõe programas de compliance e integridade de empresas brasileiras ou que aqui atuam.

73 CASTRO, Marina Grimaldi. O programa de compliance corporativo. In: Compliance no ordenamento jurídico brasileiro. DUTRA, Lincoln Zub (org.). Curitiba: Juruá, 2018. p. 169. 
Esse é o caso, reitere-se, da empresa $\operatorname{Randon}^{74}$, mencionado no início deste artigo. Igualmente, desde 2016 o teste de integridade faz parte do processo de seleção de empregados da empresa Localiza ${ }^{75}$.

Concluindo, o olhar sobre a aferição no FCPA, no UKBA e na norma ABNT NBR ISO 37001 da efetividade dos programas de compliance é recomendável para se interpretar a legislação nacional em vigor - a Lei 12.846/2013 e o Decreto 8.420/2015 - de forma a admitir a aplicação de testes de integridade no setor privado, os quais já vêm sendo utilizados há mais de década e contam, agora, com o necessário respaldo jurídico, podendo contribuir para a prevenção da corrupção na iniciativa privada, meta social ${ }^{76}$ cujo alcance é do interesse de todos nós.

\section{CONCLUSÃO}

O teste de integridade, que se notabilizou no Brasil por integrar o pacote das 10 Medidas Contra a Corrupção, já faz parte da realidade do setor privado, e não só aqui, mas também em países democráticos nos quais a prevenção da corrupção é uma pauta que concerne tanto à seara pública quanto à esfera particular.

É nesse contexto que, atualmente, os países mais avançados no combate à corrupção determinam que as organizações empresariais possuam programas de compliance e, além disso, cumpram-nos rigorosamente, sob pena de sofrer graves consequências. Se no Brasil os estímulos à implementação de programas de integridade ainda são tíbios, as corporações brasileiras que queiram se aventurar no mercado internacional não podem se abster de introduzir o compliance e suas ferramentas dentro de suas estruturas.

Conquanto tenha se destacado apenas recentemente no cenário nacional, o teste de integridade é aplicado no setor privado há mais de década por empresas preocupadas em manter um elevado padrão ético, o que atesta sua importância para prevenir a corrupção. 0 potencial de que dispõe o teste de integridade para contribuir para uma efetividade dos programas de conformidade também pode ser aferido por sua larga utilização no exterior, particularmente nos

74 NOMURA, Leandro. Você passaria no 'teste de honestidade'? Folha de São Paulo, 12 nov. 2017. Disponível em: https://www1.folha.uol.com.br/sobretudo/carreiras/2017/11/1934445-voce-passaria-noteste-de-honestidade.shtml?loggedpaywall. Acesso em: 19 mar. 2018.

75 SANCHOTENE, Diná. Empresas aplicam teste de caráter para examinar funcionários. Gazeta Online, 9 jul. 2017. Disponível em: https://www.gazetaonline.com.br/noticias/economia/2017/07/empresasaplicam-teste-de-carater-para-examinar-funcionarios-1014075340.htm. Acesso em: 3 mai. 2018.

${ }^{76}$ AGUIAR, Julio Cesar de. Teoria analítico-comportamental do direito. Por uma abordagem científica do direito como sistema social funcionalmente especializado. Porto Alegre: Nuria Fabris, 2017. p. 140. 
Estados Unidos da América e no Reino Unido, países onde essa ferramenta goza de sólido amparo normativo.

Superar em relação ao teste de integridade no setor privado as desconfianças existentes sobre o teste de integridade de agentes públicos, explicando as origens e diferenças entre ambos, bem como apresentar o fundamento normativo para a aplicação do teste de integridade nas corporações dentro dos programas de compliance, no Brasil e no exterior, foi o propósito deste estudo.

Demonstrou-se que as polêmicas envolvendo o teste de integridade de agentes públicos não são pertinentes ao teste de integridade no setor privado. Outrossim, a despeito de ter se inserido na prática empresarial sem regramento normativo, atualmente o teste de integridade no setor privado fundamenta-se na Lei $12.846 / 2013$ e no Decreto $8.420 / 2015$, tendo sua aplicação estimulada igualmente pela norma ABNT NBR ISO 37001.

É possível afirmar, portanto, que o teste de integridade no setor privado, para além de ser uma ferramenta anticorrupção de inegável valia, possui previsão no ordenamento jurídico brasileiro, conclusão essa que se presta a maximizar a segurança jurídica da formatação de programas de compliance em que esse instrumento esteja inserido.

\section{REFERÊNCIAS}

ADACHI, Pedro Podboi. Governança, risco e compliance nas empresas familiares. In: Tendências em governança corporativa e compliance. SAAD-DINIZ, Eduardo; ADACHI, Pedro Podboi; DOMINGUES, Juliana Oliveira (org). São Paulo: LiberArs, 2016. p. 69-76.

AGUIAR, Julio Cesar de. Teoria analítico-comportamental do direito. Por uma abordagem científica do direito como sistema social funcionalmente especializado. Porto Alegre: Nuria Fabris, 2017.

ASSOCIAÇÃO BRASILEIRA DE NORMAS TÉCNICAS (ABNT). ABNT NBR ISO 37001. Sistemas de gestão antissuborno. Rio de Janeiro: 2017.

ASSOCIAÇÃO NACIONAL DOS PROCURADORES DA REPÚBLICA (ANPR). Nota Técnica PRESI/ANPR/JR N017/2016. Disponível em:

http://anpr.org.br/assets/uploads/files/noticias/2016/09_Setembro/NT_MEDIDA1_testedeintegr idade.pdf. Acesso em: 28 out. 2016.

B3. Regulamento do Novo Mercado. Disponível em: http: / /www.bmfbovespa.com.br/lumis/portal/file/fileDownload.jsp?fileld=8AA8D0976069F0D70 1606FEEC81D2597. Acesso em: 5 mai. 2018. 
BECK, Francis Rafael. A dupla face do criminal compliance: da expectativa de afastamento e mitigação da responsabilidade penal à possibilidade de incremento punitivo. In: Compliance no ordenamento jurídico brasileiro. DUTRA, Lincoln Zub (org.). Curitiba: Juruá, 2018. p. 73-104.

BRASIL. Decreto $n^{\circ} 8.420$, de 18 de março de 2015 . Regulamenta a Lei $n^{\circ} 12.846$, de $1^{\circ}$ de agosto de 2013, que dispõe sobre a responsabilização administrativa de pessoas jurídicas pela prática de atos contra a administração pública, nacional ou estrangeira e dá outras providências. In: Diário Oficial da República Federativa do Brasil, Brasília, DF, 19 mar. 2015. Disponível em: http://www.planalto.gov.br/ccivil_03/_Ato2015-2018/2015/Decreto/D8420.htm. Acesso em: 10 mar. 2018.

BRASIL. Lei $n^{\circ} 12.846$, de $1^{\circ}$ de agosto de 2013. Dispõe sobre a responsabilização administrativa e civil de pessoas jurídicas pela prática de atos contra a administração pública, nacional ou estrangeira, e dá outras providências. In: Diário Oficial da República Federativa do Brasil, Brasília, DF, 2 ago. 2013. Disponível em: http://www.planalto.gov.br/ccivil_03/_ato20112014/2013/lei/l12846.htm. Acesso em: 10 mar. 2018.

CÂMARA NOTÍCIAS. Comissão exclui teste de integridade do projeto anticorrupção. 24 nov. 2016. Disponível em: http://www2.camara.leg.br/camaranoticias/noticias/DIREITO-EJUSTICA/519953-COMISSAO-EXCLUI-TESTE-DE-INTEGRIDADE-DO-PROJETO-ANTICORRUPCAO.html. Acesso em: 23 mar. 2017.

CÂMARA NOTÍCIAS. Relator sugere mudança em teste de integridade proposto no projeto de combate à corrupção. 16 ago. 2016. Disponível em: https: / / www2.camara.leg.br/camaranoticias/noticias/ADMINISTRACAO-PUBLICA/514803RELATOR-SUGERE-MUDANCA-EM-TESTE-DE-INTEGRIDADE-PROPOSTO-NO-PROJETO-DE-COMBATEA-CORRUPCAO.html. Acesso em: 17 jul. 2017.

CÂMARA NOTÍCIAS. Teste de integridade para servidor público recebe críticas em comissão especial. 9 set. 2016. Disponível em:

https: / / www2.camara.leg.br/camaranoticias/noticias/ADMINISTRACAO-PUBLICA/516017-TESTEDE-INTEGRIDADE-PARA-SERVIDOR-RECEBE-CRITICAS-EM-COMISSAO-ESPECIAL.html. Acesso em: 18 jul. 2017.

CARVALHO, Paulo Roberto Galvão de. Legislação anticorrupção no mundo: análise comparativa entre a Lei Anticorrupção brasileira, o Foreign Corrupt Practices Act norte-americano e o Bribery Act do Reino Unido. In: Lei Anticorrupção. QUEIROZ, Ronaldo Pinheiro de; SOUZA, Jorge Munhós (org.). Salvador: Juspodivm, 2015. p. 35-62.

CASTRO, Marina Grimaldi. O programa de compliance corporativo. In: Compliance no ordenamento jurídico brasileiro. DUTRA, Lincoln Zub (org.). Curitiba: Juruá, 2018. p. 159-177.

CONJUR. Delegado da PF critica teste de integridade e validação de prova ilícita. 18 out. 2016. Disponível em: https://www.conjur.com.br/2016-out-18/delegado-pf-critica-testeintegridade-uso-prova-ilicita. Acesso em: 18 jul. 2017.

COUNCIL OF EUROPE. Integrity Testing - Aspects of Implementation Drafted by Dr. Tilman Hoppe, LL.M., Project Long-Term Adviser 19 December 2014. 
ENCYCLOPAEDIA BRITANNICA. International Organization for Standardization. 2018. Disponível em: https://www.britannica.com/topic/International-Organization-for-Standardization. Acesso em: 9 jun. 2018.

ENGINEERING NEWS-RECORD (ENR). ENR's 2017 Top 250 International Contractors 1-100. Ago. 2017. Disponível em: https://www.enr.com/toplists/2017-Top-250-International-Contractors-1. Acesso: 20 mai. 2018.

FONSECA, João Bosco Leopoldino da. Conformidade Legal. In: Compliance e integridade: aspectos teóricos e práticos. OLIVEIRA, Luiz Gustavo Miranda de (org.). Belo Horizonte: D'Plácido, 2017. p. 87-111.

INTEGRITY METER. Teste períodico. Integrity Meter, recruit to perfection. Disponível em: http://www.integritymeter.com/pt-br/periodic. Acesso em: 20 mai. 2018.

JUNGES, Cíntia. Após Lava Jato, teste de integridade ganha espaço como critério de seleção. Gazeta do Povo, 31 mar. 2017. Disponível em: https://www.gazetadopovo.com.br/economia/pos-e-carreira/apos-lava-jato-teste-deintegridade-ganha-espaco-como-criterio-de-selecao-cahhjopjdnw7ombm3z8noojhj/. Acesso em: 15 abr. 2018.

LEBOWITZ, Shana. 6 sample questions employers ask to assess your personality. Business Insider, 16 jul. 2015. Disponível em: http://www.businessinsider.com/sample-questions-onpersonality-tests-2015-7. Acesso em: 9 jun. 2018.

LIMA, Carlos Fernando dos Santos; MARTINEZ, André Almeida Rodrigues. Compliance Bancário: Um Manual Descomplicado. São Paulo: Quartier Latin, 2018.

MAEDA, Bruno Carneiro. Programas de Compliance Anticorrupção: importância e elementos essenciais. In: Temas de Anticorrupção e Compliance. DEL DEBBIO, Alessandra; MAEDA, Bruno Carneiro; AYRES, Carlos Henrique da Silva (org.). Rio de Janeiro: Elsevier, 2013. p. 167-201.

MIGALHAS. Senado aprova projeto das “10 medidas contra a corrupção”. 27 jun. 2019. Disponível em: https://www.migalhas.com.br/Quentes/17,MI305234,11049-

Senado+aprova+projeto+das+10+medidas+contra+corrupcao. Acesso em: 18 jul. 2019.

MILIONI, Armando Zeferino; OLIVEIRA, Adjame Alexandre Gonçalves. Bayes contra o teste de integridade. Jota, 3 set. 2016. Disponível em: https://www.jota.info/especiais/bayes-contra-oteste-de-integridade-03092016. Acesso: 12 nov. 2016.

MINISTRY OF JUSTICE. The Bribery Act 2010 Guidance. 11 fev. 2012. Disponível em: https://www.gov.uk/government/uploads/system/uploads/attachment_data/file/181762/briber y-act-2010-guidance.pdf. Acesso em: 8 abr. 2018.

MUNGIU-PIPPIDI, Alina. The quest for good governance: how societies develop control of corruption. London: Cambridge University Press, 2015.

NASCIMENTO, José Carlos Martins do. Compliance e legislação internacional. In: Compliance e integridade: aspectos teóricos e práticos. OLIVEIRA, Luiz Gustavo Miranda de (org.). Belo Horizonte: D'Plácido, 2017. p. 233-271. 
TESTE DE INTEGRIDADE NO SETOR PRIVADO: ESTADO DA ARTE

NOMURA, Leandro. Você passaria no 'teste de honestidade'? Folha de São Paulo, 12 nov. 2017. Disponível em: https://www1.folha.uol.com.br/sobretudo/carreiras/2017/11/1934445-vocepassaria-no-teste-de-honestidade.shtml?loggedpaywall. Acesso em: 19 mar. 2018.

ODEBRECHT. Comunicado Odebrecht - Operación Lava Jato. 22 jun. 2015. Disponível em: https://www.odebrecht.com/es/comunicacion/releases/comunicado-odebrecht-operacion-lavajato. Acesso em: 10 mai. 2018.

OFFICE OF TECHNOLOGY ASSESSMENT (OTA), U.S. CONGRESS. The Use of Integrity Tests for Pre-Employment Screening. Sep. 1990. Disponível em: http://ota.fas.org/reports/9042.pdf. Acesso em: 20 nov. 2017.

OFFICE OF THE UNITED STATES ATTORNEYS. United States Attorney's Manual - USAM. Disponível em: https: / /www. justice.gov/usam/usam-9-28000-principles-federal-prosecution-businessorganizations\#9-28.800. Acesso em: 3 mai. 2018.

ORGANIZAÇÃO PARA COOPERAÇÃO E DESENVOLVIMENTO ECONÔMICO - OCDE. Phase 3 report on implementing the OECD Anti-Bribery Convention in Brazil. Outubro de 2014. Disponível em: www.oecd.org/daf/anti-bribery/Brazil-Phase-3-Report-EN.pdf. Acesso em: 15 abr. 2018.

RADIOAGÊNCIA. Associação que representa carreiras de estado critica testes de integridade. 15 ago. 2016. Disponível em:

http: / / www2.camara.leg.br/camaranoticias/radio/materias/RADIOAGENCIA/514792-

ASSOCIACAO-QUE-REPRESENTA-CARREIRAS-DE-ESTADO-CRITICA-TESTES-DE-INTEGRIDADE.html. Acesso em: 5 mai. 2017.

RAMOS, Raeclara Drummond. Norma ABNT NBR ISO 37001: Sistemas de Gestão Antissuborno. In: Compliance como instrumento de combate à corrupção. MARQUES, Jader; PORTO, Vinicius (org.). Porto Alegre: Livraria do Advogado, 2017. p. 129-137.

SANCHOTENE, Diná. Empresas aplicam teste de caráter para examinar funcionários. Gazeta Online, 9 jul. 2017. Disponível em:

https://www.gazetaonline.com.br/noticias/economia/2017/07/empresas-aplicam-teste-decarater-para-examinar-funcionarios-1014075340.html. Acesso em: 3 mai. 2018.

SANTOS, Renato. Teste de integridade: como mapear o DNA ético do seu futuro colaborador? Endeavor Brasil, 14 mar. 2017. Disponível em: https://endeavor.org.br/teste-de-integridadecomo-mapear-o-dna-etico-seu-futuro-colaborador/. Acesso em: 19 mar. 2018.

SANTOS, Renato. Testes de integridade devem ter caráter educativo, e não julgador. 0 Estado de São Paulo, 31 mar. 2018. Disponível em: https://politica.estadao.com.br/blogs/faustomacedo/testes-de-integridade-devem-ter-carater-educativo-e-nao-julgador/. Acesso em: 3 mai. 2018.

SARAIVA, Jacilio. Novos tipos de testes psicológicos avaliam postura ética e preconceitos. Valor Econômico, 2 out. 2014. Disponível em: http://www.valor.com.br/carreira/3718978/novostipos-de-testes-psicologicos-avaliam-postura-etica-e-preconceitos. Acesso em: 9 jun. 2018. 
STRECK, Lenio. O pacote anticorrupção do Ministério Público e o fator Minority Report.

Consultor Jurídico, 3 mar. 2016. Disponível em: http://www.conjur.com.br/2016-mar-

03/senso-incomum-pacote-anticorrupcao-mpf-fator-minority-report. Acesso em: 28 ago. 2016.

SUBCHEFIA DE ASSUNTOS PARLAMENTARES. EMI Nº 000112009 - CGU/MJ/AGU. Brasília, 23 out. 2009. Disponível em:

http://www.planalto.gov.br/ccivil_03/projetos/EXPMOTIV/EMI/2010/11\%20-

\%20CGU\%20MJ\%20AGU.htm. Acesso em: 8 abr. 2018.

TERRA. Teste online detecta nível de ética no trabalho. Terra, 26 out. 2005. Disponível em: http: //tecnologia.terra.com.br/noticias/0, Ol726198-El15608,00-

Teste+online+detecta+nivel+de+etica+no+trabalho.html. Acesso em: 12 mar. 2018.

THE NATIONAL ARCHIVES. United Kingdom Bribery Act 2010. Disponível em:

https://www.legislation.gov.uk/ukpga/2010/23/contents. Acesso em: 12 mar. 2018.

THE UNITED STATES DEPARTMENT OF JUSTICE. Foreign Corrupt Practices Act of 1977.

Disponível em: https://www.justice.gov/criminal/fraud/fcpa/docs/fcpa-english.pdf. Acesso em: 12 mar. 2018.

UBALDO, Flávia Safadi. Lei Anticorrupção: a importância do programa de compliance no cenário atual. In: 0 compliance como instrumento de prevenção e combate à corrupção. PORTO, Vinicius; MARQUES, Jader (org). Porto Alegre: Livraria do Advogado, 2017. p. 119-137.

UNITED STATES SENTENCING COMMISSION - USSC. Guidelines Manual. Washington, 1 nov. 2016. Disponível em: https://www.ussc.gov/sites/default/files/pdf/guidelines-

manual/2016/GLMFull.pdf. Acesso em: 9 jun. 2018.

VERÍSSIMO, Carla. Compliance: incentivo de adoção de medidas anticorrupção. São Paulo: Saraiva, 2017.

VERSLUIS, Esther. Compliance Problems in the EU. What potential role for agencies in securing compliance? Paper prepared for the 3rd ECPR General Conference, Budapest, 8-10 September 2005 Panel 3.3: 'Theorizing Regulatory Enforcement and Compliance' Disponível em: http://regulation.upf.edu/ecpr-05-papers/eversluis.pdf. Acesso em: 5 mai. 2018.

ZAGARIS, Bruce. Transnational corruption in Brazil: the relevance of the U.S. experience with the Foreign Corrupt Practices Act. In: Temas de Anticorrupção e Compliance. DEL DEBBIO, Alessandra; MAEDA, Bruno Carneiro; AYRES, Carlos Henrique da Silva (org.). Rio de Janeiro: Elsevier, 2013. p. 55-78. 


\section{COMO FAZER REFERÊNCIA AO ARTIGO (ABNT):}

AGUIAR, Julio Cesar de; MATIAS, Flávio Pereira da Costa. Teste de integridade no setor privado: estado da arte. Revista Eletrônica do Curso de Direito da UFSM, Santa Maria, RS, v. 14, n. 3, e33399, set./dez. 2019. ISSN 1981-3694. DOI: http://dx.doi.org/10.5902/1981369433399. Disponível em: https://periodicos.ufsm.br/revistadireito/article/view/33399 Acesso em: dia mês. ano.

\section{Direitos autorais 2019 Revista Eletrônica do Curso de Direito da UFSM}

Editores responsáveis: Rafael Santos de Oliveira e Angela Araujo da Silveira Espindola

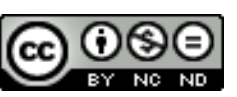

Esta obra está licenciada com uma Licença Creative Commons Atribuição-NãoComercial-SemDerivações 4.0 Internacional.

\section{SOBRE OS AUTORES}

\section{JuLIO CESAR DE AGUIAR}

Bacharel em Direito e mestre em Filosofia pela Universidade Federal de Goiás. Doutor em Direito pela Universidade Federal de Santa Catarina e PhD in Law pela University of Aberdeen, UK. Professor da Graduação e do Mestrado em Direito da Universidade Católica de Brasília, atuando na linha de pesquisa Direito, Ciências, Instituições e Desenvolvimento. Pesquisador Colaborador Pleno do Instituto de Psicologia da Universidade de Brasília. Procurador da Fazenda Nacional, atuando na Consultoria de Assuntos Financeiros do Ministério da Fazenda. Seus interesses acadêmicos atuais concentram-se nos seguintes temas: Direito como Sistema de Práticas Culturais, Análise Comportamental do Direito, Análise Econômica do Direito, Direito como Sistema Complexo Evolutivo, Sociologia da Ciência do Direito, Filosofia do Direito, Hermenêutica e Argumentação Jurídica, Direito como Comportamento Verbal, Direito como Sistema Social Autopoiético, Sistemas Sociais, Pensamento Social de Niklas Luhmann.

\section{FLÁvio PeREIRA da Costa Matias}

Bacharel em direito pela Universidade Federal da Paraíba (2009), com período sanduíche no ano letivo 2006-2007 na Université Lyon III - Jean Moulin, onde obteve o Diplôme d'Etudes Universitaires Français. Pós-graduado em Direito do Estado pela Fundação Faculdade de Direito - UFBA (2011). Pós-graduado em Sistema de Justiça Criminal pela Escola Superior do Ministério Público da União (2017). Mestrando em Direito pela Universidade Católica de Brasília. Foi professor da Escola Superior do Ministério Público da União e em cursos de atualização jurídica na Procuradoria da República na Bahia, nos anos de 2014 e 2015. Instrutor de cursos de atualização jurídica na Procuradoria da República em Sergipe. É procurador da República do Ministério Público Federal desde fevereiro de 2013, atuando principalmente nos seguintes temas: combate à corrupção, improbidade administrativa, crimes contra a administração pública, defesa dos direitos humanos e proteção do meio ambiente e de direitos e interesses coletivos. 